\title{
URBAN AND RURAL CULTURAL LANDSCAPES IN THE FUNCTIONAL URBAN REGION OF BRATISLAVA
}

\author{
JÁN HANUŠIN, MIKULÁŠ HUBA, VLADIMÍR IRA, PETER PODOLÁK \\ Ján Hanušin, Mikuláš Huba, Vladimír Ira, Peter Podolák \\ Geografický ústav SAV, Štefánikova 49, 81473 Bratislava, Slovak Republic \\ hanusin@savba.sk
}

\begin{abstract}
The characteristics both of urban and rural cultural landscapes were studied on the example of the NE sector of Bratislava Functional Urban Region (FUR), consisting of 18 municipalities with population of about 85,000 . The aim of the paper is to assess three main domains - demographic changes, quality of life and environmental quality - in order to specify differences between the rural and urban cultural landscapes and classification of the area according to the urban/rural characteristics. The resulting distribution of urban/rural areas even with some deviations confirmed the general trend of an increasing rural character of the area with the increasing distance from Bratislava.
\end{abstract}

Key words: Urban/rural space, cultural landscape, Bratislava Functional Urban Region, demographic situation, environmental quality, quality of life, land cover

\section{INTRODUCTION}

Cultural landscape is often interpreted depending on the ambivalent understanding of the notion "cultural". On the one hand, cultural can be interpreted as anything related to culture, history, cultural heritage. On the other hand, it can be a synonym for civilisation. According to the first interpretation, cultural landscape is the landscape reflecting traditional features of local/regional type/types of landscape, while the other means any landscape changed by human activities. In this sense as well as according to the European Landscape Convention (ELC, www.coe.int/europeanlandscapeconvention) landscape protection means actions to conserve and maintain the significant or characteristic features of a landscape, justified by its heritage value derived from its natural configuration and/or from human activity. Other notions relevant from the point of view of the study and compatible with the ELC philosophy include "landscape quality objective", "landscape planning" and "landscape management". Pursuing the definition of Hanušin et al. (2000), cultural landscape is originally a natural landscape recreated by human activities. The economic and social processes also accompany the natural processes going on in cultural landscape. Humans create a secondary landscape structure. According to the intensity of such recreation, cultural landscape can be managed or abandoned. Estimating by the dominant function, cultural landscape can be agricultural (specifically vine growing), urban, rural, industrial and the like. Cebecauerová (2007) reports that the study of changes under way in (cultural) landscape attracts increased attention as the human impact in 
landscape is ever more evident. Landscape changes that took place in Slovakia since the 1950s are historically unparalleled in terms of speed, intensity and scope. In time of global challenges, planning and forecasting of developments in the sphere of landscape, the efforts identify the present status of landscape are now concentrated on interpretation of landscape changes and those of the dynamics of its individual components.

Cultural landscapes in Slovakia constitute a continuum from rural to urban landscapes, which have often developed over long periods of time. The complex of urbanization processes caused differences in formation of two basic landscape types: urban and rural. In the last decades, expansion of urban landscape becomes a more complex and unequal procedure in our planet (Antrop, 2004). Urban landscape is the result of interrelated economic, demographic, social-cultural, political, technological and environmental procedures that form its character. In urban landscape these procedures cause dynamical changes in land use as well as changes in man's behaviour and his way of life. Urban regions are considered hybrid landscapes where different urban and rural elements are inseparably mixed. This leads to new challenges, e.g. for the protection of natural resources, cultural heritage, but it also provides new opportunities for integrative approaches to landscape management that seek to establish beneficial relationships between urban and rural (Antrop, 2006).

The urban cultural landscape shapes the character of the city, town or village, a combined work of people, place and time, defining it as unique. Urban heritage areas are legible to both local citizens and the visitors. Urban cultural landscapes are multi-sensory vessels for spirit of place that combine tangible and intangible heritage values. There is a challenge in oversimplifying the urban landscape and in attributing only the most obvious aspects. Those who live in or study an urban landscape perceive this complexity as a composite that in total represents the spirit of the place within the urban landscape. The cultural landscape of many urban areas comprises significant part of the overall landscape space and contributes significantly to the spirit and character of the place.

Rural landscape is traditionally connected with agriculture, forestry and fishing. It is the storage of natural resources for the development of urban areas. It gives space for the infrastructure necessary for operation of urban environment. It serves as an open space for the development and expansion of urban landscape; it is a space where comes about also the significant part of consumption of inhabitants of urban environment as well as their recreation and relaxing activities (Claval, 2005).

According to Palang (2009), conventionally the term "landscape" relates more to the rural and less to the urban. The landscape definition as stated in the ELC also includes the development of the landscape, pointing at the natural and human-induced processes that have shaped the landscape. As stated by Primdahl and Swaffield (2009), European rural landscapes are currently in transition due mainly to two processes: structural changes in agriculture and various forms of urbanisation. Authors of this article rather tend to interpret cultural landscape as a territory with conventional ways of management, conserved traditional properties and an original functional structure of use.

Functional urban regions are empirically delineated on the basis of intensive daily job-commuting flows between the core of the region and its hinterland. They are defined as spatially contiguous groups of municipalities, which are internally coherent and relatively self-contained in terms of daily commuting. They represent areas where people live and work at the same time. There has been some consensus in the recent literature that a regional design derived from the concept of functional urban region provides a meaningful spatial framework for analysing population and other human geographical phenomena. Many empirical studies brought convincing evidence that the territorial units created for the needs of public administration (administrative districts, etc.) do not conform to the idea of regional units suitable for the analysis of spatial human activities and behaviour because 
they do not correspond to the geographical concept of region. In Slovakia, several attempts have been made to identify such areas (Bezák, 1990, 2000).

The functional urban region of Bratislava is spatially the largest and most populated in Slovakia with population of about 680,000 in 110 municipalities. The response of academics to the massive spatial and social changes in landscape caused by industrialization and urbanization was captured in the concept of urban - rural continuum. Substantial transformation of the landscape had a number of major economic, social and cultural impacts and consequences resulting in continuous graduation of ways of life between rural areas and large cities (Halfacree, 2009).

The definition of the urban and the rural space or their divide is not unambiguous. Individual authors often adapt it to their objectives and orientation of their studies. An overview of the terminology (emphasizing urban ecology) and a manual of its standardization can be found in, for instance, MacGregor-Fors (2011). Interesting seems MacGregor-Fors' proposal that the agriculturally intensively exploited non-urban areas in the hinterland of cities referred to as rural should be called extra-urban. This author also often uses the term urban-rural gradient for the delimitation of the urban-rural divide introduced by McDonnel and Picket in 1990. The paradigm of the urban-rural gradient is used in the study of urbanization's impact on ecosystems. Toit and Cilliers (2011) report that while establishing the urban-rural gradient, data from the landscape metrics, demographic or physical data are seldom used. An example of exploitation of a combination of such data for the establishment of the urban-rural gradient is the study of Hahs and McDonnell (2006). For the delimitation of the urban-rural gradient on an example of the Australian city of Melbourne, they used 17 metrics from three principal domains (demographic, physical - physical properties of the aerial image of the territory - and the landscape domain). Four criteria were established (via the PCA - principal component analysis - method) that characterize the urban character of a territory. Along with a specific physical criterion it was the population number per unit of urban land cover, shape index of the landscape unit and the dominant land cover.

The above-mentioned but also other studies demonstrate that it is practically impossible to formulate a universal and generally applicable definition of urban or rural spaces.

\section{STUDY AREA AND METHODOLOGY}

The characteristics both of urban and rural cultural landscapes were studied on the example of the NE sector of Bratislava Functional Urban Region (FUR) consisting of eighteen municipalities (including two Bratislava's city districts and three towns), with population of about 85,000 and an area of $408 \mathrm{~km} 2$. The study area is the transitional zone between the Western Carpathian mountain system (Little Carpathians - up to 695 m a.s.l.) and the Western Pannonian basin lowlands (Podunajská Lowland $130 \mathrm{~m}$ a.s.l.). With an exception of the forested semi-natural landscape in the Little Carpathians, different types of cultural landscape - urban, suburban and rural with various type of human activities like viniculture, agriculture, forestry, tourism, industry, nature and culture heritage protection - prevail in the remaining area. The study area is administratively divided into the city of Bratislava and the Region of Bratislava (Pezinok district). It is one of the most developed parts of the country situated along the developing axe heading from Bratislava towards the north-east. The close neighbourhood of the Capital, with its relatively very high economic and financial potential impacts the economic development in the whole region and "produces" thousands of people with the tendency to move towards the hinterland of Bratislava. This intensive process has a basic effect on spatial organization of the territory. 
The aim of the paper is to assess the demographic changes, quality of life and environmental quality in order to specify differences between the rural and urban cultural landscapes and classification of the area according to the rural-urban characteristics.

In relationship to the assessment of the reality, different notions and tools have been developed. For the purpose of this study, three categories applied in the sphere of the sustainable development are used (Huba et al., 2000):

- Principles,

- Criteria,

- Indicators (indexes).

The categories are hierarchically aligned from the most general principles over specifying criteria up to individual specific indicators of sustainable development. There are not always sharp limits between the above-mentioned three categories especially the principles and criteria often overlap. However, generally the principles should be universal while the criteria and indicators are chosen with regard to the particular conditions, the assessed object and the purpose of assessment. Likewise, the hierarchic arrangement from the most general principles to the most specific indicators holds. It means that the chosen indicators and principles should correspond to the adopted principles.

Three principal domains were assessed to establish the urban/rural character for each of the eighteen municipalities:

- Demographic

- Environmental quality

- Quality of life

In agreement with Hahs and McDonnell (2006) and Toit and Cilliers (2011), for the optimal delimitation of the urban-rural divide, it is appropriate to use comprehensive indicators of different nature, which enhance the objectivity of results. For each principal domain, individual criteria and indicators were adopted to help develop the resulting value from the point of view of the urban/rural character. Demographic and quality of life domains are related only to the permanently inhabited areas. Environmental quality domain is related to the whole cadastral territory. All domains are considered to have equal importance (weight). The cadastral territory of a municipality is the basic unit for the assessment. For each cadastral territory and each principal domain the urban/rural character was rated using the 5-level scale: urban, mostly urban, transitive, mostly rural and rural. The very final urban/rural character of the cadastral territory was set as an average value of three principal domains values (using the same 5-level scale).

Strengthening of the urban nature in case of larger populations concentrated in urban settlements with prevalence of immigration to the settlements can be expected in terms of the relationship of the demography to the urbanity or rurality of a territory. The relationship of life quality to the urbanity/ rurality is more ambiguous and definitely depends on the choice and weight of individual indicators. On the one side, many classical measurable indicators suggest the continual proportion between their high value, quality of life and urbanity (availability of domestic appliances, amenities and infrastructure of the settlement, consumption items, accessibility of education and services), while indicators of life quality, some of them not easily quantifiable, with optimum values typical for rural areas such as the quality of environmental components (air, water and soil), noise and light pollution, aesthetic assets of landscape, life style, etc. may exist on the other side. Environmental quality vs. urbanity/rurality in our interpretation is given by the nature of land cover. As a matter of fact, urban nature of the territory is in continual proportion to the percentage of artificial surface areas. 


\section{RESULTS}

\section{DEMOGRAPHIC DOMAIN}

The basic feature of the population's development in the region of interest is its close bond to the settlement development of Bratislava as the biggest agglomeration in Slovakia. While the extensive phase of urbanization in Slovakia (typical for mass immigration to towns and depopulation of the country) peaked during the previous decades, approximately in the second half of the 1990s this trend turned around and the towns began to loose population. Especially the villages in their hinterland became attractive. The villages of the Sub-Carpathian Region are among the most attractive in the country (Moravanská, 2010, Podolák, 2007, Podolák et al., 2011, Slavík and Kurta, 2007, Šveda, 2009).

Tab. 1: Selected characteristics of suburbanization

\begin{tabular}{|l|c|c|c|}
\hline MUNICIPALITY & $\begin{array}{c}\text { TOTAL POPULATION } \\
\text { INCREASE } \\
2001-2010 \\
\text { (in \%o) }\end{array}$ & $\begin{array}{c}\text { IMMIGRATION } \\
\text { FROM } \\
\text { BRATISLAVA } \\
\text { (in \%) ** }\end{array}$ & $\begin{array}{c}\text { CHANGE IN NUMBER } \\
\text { OF NEW FLATS } \\
-2001-2007 \\
\text { (in \% to 2001) }\end{array}$ \\
\hline Budmerice & 16.1 & 28.0 & 9.2 \\
\hline Častá & 6.9 & 29.7 & 6.0 \\
\hline Dolany & 2.1 & 29.8 & 8.2 \\
\hline Dubová & 7.5 & 29.7 & 6.8 \\
\hline Chorvátsky Grob & 81.1 & 59.0 & 94.8 \\
\hline Limbach & 42.4 & 54.0 & 23.4 \\
\hline Modra & 5.4 & 28.5 & 7.4 \\
\hline Pezinok & 6.0 & 31.0 & 9.7 \\
\hline Píla & 20.2 & 23.5 & 13.6 \\
\hline Slovenský Grob & 14.1 & 44.8 & 7.2 \\
\hline Svätý Jur & 13.6 & 51.5 & 6.7 \\
\hline Šenkvice & 10.1 & 22.3 & 4.5 \\
\hline Štefanová & 0.6 & 12.0 & 23.1 \\
\hline Viničné & 32.8 & 24.4 & 12.2 \\
\hline Vinosady & 24.6 & 18.9 & 4.0 \\
\hline Vištuk & 3.0 & 33.7 & 5.0 \\
\hline Rača & 2.4 & - & 21.7 \\
\hline Vajnory & 31.3 & - & \\
\hline & & & 0.9 \\
\hline
\end{tabular}

* The number indicates the average annual total population increase per 1.000 municipality inhabitans in period 2001-2010

** Number indicates the percentage of immigrants from Bratislava from the total number of immigrants to the municipality in period 2001-2008

Since 1970, population loss becomes evident in small and medium-sized municipalities of the region (Štefanová, Dubová, Dol’any, Vinosady). Population also decreased in big villages (Častá, Slovenský Grob, Chorvátsky Grob, Šenkvice) and the town of Svätý Jur. On the other side, urban 
centres of the region (such as Pezinok and Modra) maintained the population increase (which revived in almost all other villages after1991) all over the 1970s. Rača and Vajnory are specific. These two traditionally wine growing villages became administrative parts of Bratislava in 1946 although they conserved the rural character for a long time. In Vajnory it is evident even today with the contribution of the existing spatial divide between the old and the new built-up parts. Construction of big housing estates started in Rača after 1970 and since then the village gradually merged with the neighbouring urban parts of the city. The Slovak National Council adopted a new Act on Bratislava after 1990. Pursuing this Act, these two former villages became urban districts with their own government, which provides them with certain independence.

The level of overall population change depends on the values of two components. The natural component of the overall increase after 2000 is very low; fewer babies are born than the number of dead. The level of migration balance then determines the overall increase values. It several fold exceeds the natural increase. The villages which most gain by migration are Chorvátsky Grob, Limbach, Viničné, Vinosady a Vajnory; it means the ones where new residential quarters with the highest increase of new dwellings were built after 2000. These villages also boast the highest values of overall population increase (Table 1).

The pronounced suburbanising tendencies in hinterland of the Capital prove (beside other) the fact that the out-migration flows from Bratislava to rural municipalities are several fold more intensive than in-migration. More people move out of Bratislava to all studied municipalities than vice versa. It should also be added that many inhabitants who move out of the city do not change their domicile or they keep their original dwelling. It means that the out-migration rate is in reality even higher than the available data and as the rural municipalities loose considerable amounts proceeding from taxes they try to compensate it by, for instance, an increased real estate tax for the not permanent residents.

\section{QUALITY OF LIFE DOMAIN}

Apparently, quality of life is a phenomenon representing the character or the evaluation of the human life itself. The complexity of human life is due to a number of its parts that sometimes overlap and to the different links that exist between them. According to Massam (2002), quality of life consists of a set of components that represent the partial components of human life and are evaluated by means of selected types of indicators.

Amenities and infrastructure are crucial for sustainable development and acceptable quality of life in communities. Experience from the post-war to more recent situation in settlements has repeatedly shown that infrastructure (e.g. local services like schools, shops, public transport, etc.) is needed at any stage of settlement development and the life of communities. Lessons from settlements in Slovakia over the past 50 years have shown that the lack of infrastructure to support residents slows the process of building a locality-based community and can create long-term problems for the social and economic well-being and opportunities of the new development (Ira and Andráško, 2010).

Saturation index of infrastructure in municipalities (58 indicators clustered in ten clusters - transport infrastructure, technical infrastructure, financial services, accommodation facilities, shopping facilities, health services, cultural and educational facilities, social services, and sport facilities) was briefly analysed in the studied region. Saturation index of the infrastructure of everyday life (Jarvis, 2005) was calculated from 19 indicators and its values were also analysed from the spatial point of view. The analysis of the saturation index of infrastructure shows spatial differentiation and a significant rural-urban divide. Perception of available amenities and quality of life was assessed through a survey conducted in selected municipalities (two urban and fourteen rural municipalities). 
The results of the survey point to greater satisfaction with life conditions in rural municipalities influenced by the suburbanization process. The majority of respondents believe that both, infrastructure and overall quality of life in rural municipalities have been developing recently.

\section{ENVIRONMENTAL DOMAIN}

Overlapping of natural, rural and urban landscapes and their identification problems are most pronounced in hinterlands of big cities more so if they are situated in the vicinity of landscape units such as mountain ranges, wetlands or a high quality farmland (Huba et al., 2010, Huba et al., 2011). Bratislava and its FUR is a typical example.

Characteristics of land cover, especially the proportion of artificial surfaces in land cover were used as partial indicators for the delimitation of the divide between the rural and urban environments. Likewise, on the basis of land cover characteristics a rurality index was compiled from the percentage of land cover categories defined as rural or urban. These two are characterized by land cover properties regarding the natural or close to natural surfaces. Precisely the high percentage of artificial surfaces (AS) and the low rate of ecological stability are typical for urban environment while the rural environment is characterized by low percentage of AS and a higher level of ecological stability. Values of partial indicators like in other cases were classified into five categories based on Corine Land Cover (CLC) 2000 definitions and data. Artificial surfaces became the eponymous category of CLC, which also covered the urbanized fabric, industrial, commercial and transport areas, mining, dumping sites and construction sites along with the artificial, other than farming greenery. The highest proportion of AS in the cadastral territory corresponds to the urban districts of Bratislava - Vajnory (34 per cent) and Rača (24 per cent). Regarding the high representation of industrial, warehouse and transport areas, the non-settlement AS prevail in both cases. A specific case is the village Píla with the cadastral territory situated in a narrow densely built-up valley of the local brook where the AS occupy even $76 \%$ of total area. Distance from the centre of Bratislava measured to the centre of concerned municipalities was used as the hypothetic reference indicator for the rurality rate. It was found out that in case of the AS there are significant hints to the existence of a negative correlation between the proportion of AS in the area of the cadastral territory and the distance from Bratislava's centre. Correlation coefficient $(-0,64)$ which is on the bottom limit of correlation reliability for such a small set suggests that the proportion of AS drops with the increasing distance from Bratislava's centre; in other words the rurality rate measured by this indicator increases.

Natural or seminatural areas, which regarding their great size in some municipalities complicate division of the territory into target categories proved to be foreign elements in the search for differences. This is the reason, why in case of the Bratislava's FUR such procedures aimed at the delimitation of the rural/urban environment rate were chosen, which eliminated natural areas. Individual LC categories were further broken into three basic groups: natural-rural-urban, where forest and seminatural areas (category 3 CLC), wetlands (category 4 CLC) and water bodies (category 5 CLC) were classed with the group natural; group rural covered the agricultural areas (category 2 CLC) and the group urban contained artificial surfaces (category 1 CLC). Areas or portions of natural areas, which are irrelevant in terms of urban/rural environment assessment, were excluded in the following analyses. The value of the rurality index (LCIr - in terms of LC) was obtained by the division of the urban/rural area proportions:

$$
\mathrm{LCI}_{\mathrm{r}}=\frac{\text { Agricultural areas (category } 2 \mathrm{CLC}, \text { in } \% \text { of the cadastre area) }}{\text { Artificial surfaces (category } 1 \mathrm{CLC}, \text { in } \% \text { of the cadastre area) }}
$$


The resulting urbanity/rurality values in terms of the environmental quality obtained as the average of two analysed indicators were divided into five categories.

It means that only Bratislava -Vajnory and the small village of Píla (for the above-quoted reasons) appear as urban areas. Bratislava - Rača, Pezinok and Modra are prevailingly urban. Transitive are the municipalities located in the central part of the territory (Slovenský Grob, Limbach, Viničné, Vinosady, Šenkvice). Municipalities grouped in two parts of the territory boast the mostly rural to rural character. Regarding the distance from Bratislava, the larger cluster of such municipalities in the north-eastern part of the studied region is no surprise. However, what does surprise is the status of the rural cadastral territory of the settlements in the close hinterland of Bratislava. Land cover structure is the reason in case of Chorvátsky Grob where almost 90 of the cadastral territory (situated in the Podunajská Lowland) is arable land. Svätý Jur, in spite being a town, possesses a low portion of artificial surfaces and a high rurality index value - the reason why this settlement has been classified among the rural ones.

\section{THE FINAL URBAN/RURAL CHARACTER OF THE BRATISLAVA FUR}

The resulting values revealed some expected results (Table 2, Fig.1):

- Two Bratislava urban districts (Vajnory and Rača) display the most pronounced urban character,

Tab. 2: Assessment of urban/rural character of 3 principal domains and final urban/rural character of individual municipalities in Bratislava FUR (5 urban to 1 rural).

\begin{tabular}{|c|c|c|c|c|}
\hline MUNICIPALITY & $\begin{array}{l}\text { Demographic } \\
\text { domain }\end{array}$ & $\begin{array}{l}\text { Quality of life } \\
\text { domain }\end{array}$ & $\begin{array}{l}\text { Environmental quality } \\
\text { domain }\end{array}$ & $\begin{array}{c}\text { Final urban/ Rural } \\
\text { character }\end{array}$ \\
\hline Budmerice & 2 & 2 & 2 & 2 \\
\hline Častá & 2 & 2 & 2 & 2 \\
\hline Dol'any & 2 & 1 & 1 & 1 \\
\hline Dubová & 1 & 1 & 2 & 1 \\
\hline Chorvátsky Grob & 4 & 2 & 1 & 2 \\
\hline Limbach & 4 & 2 & 3 & 3 \\
\hline Modra & 5 & 4 & 4 & 4 \\
\hline Pezinok & 5 & 4 & 4 & 4 \\
\hline Píla & 1 & 1 & 5 & 2 \\
\hline Slovenský Grob & 3 & 2 & 3 & 3 \\
\hline Svätý Jur & 5 & 3 & 1 & 3 \\
\hline Šenkvice & 2 & 3 & 3 & 3 \\
\hline Štefanová & 1 & 1 & 1 & 1 \\
\hline Viničné & 3 & 2 & 3 & 3 \\
\hline Vinosady & 2 & 2 & 3 & 2 \\
\hline Vištuk & 1 & 2 & 1 & 1 \\
\hline Rača & 5 & 5 & 4 & 5 \\
\hline Vajnory & 5 & 5 & 5 & 5 \\
\hline
\end{tabular}



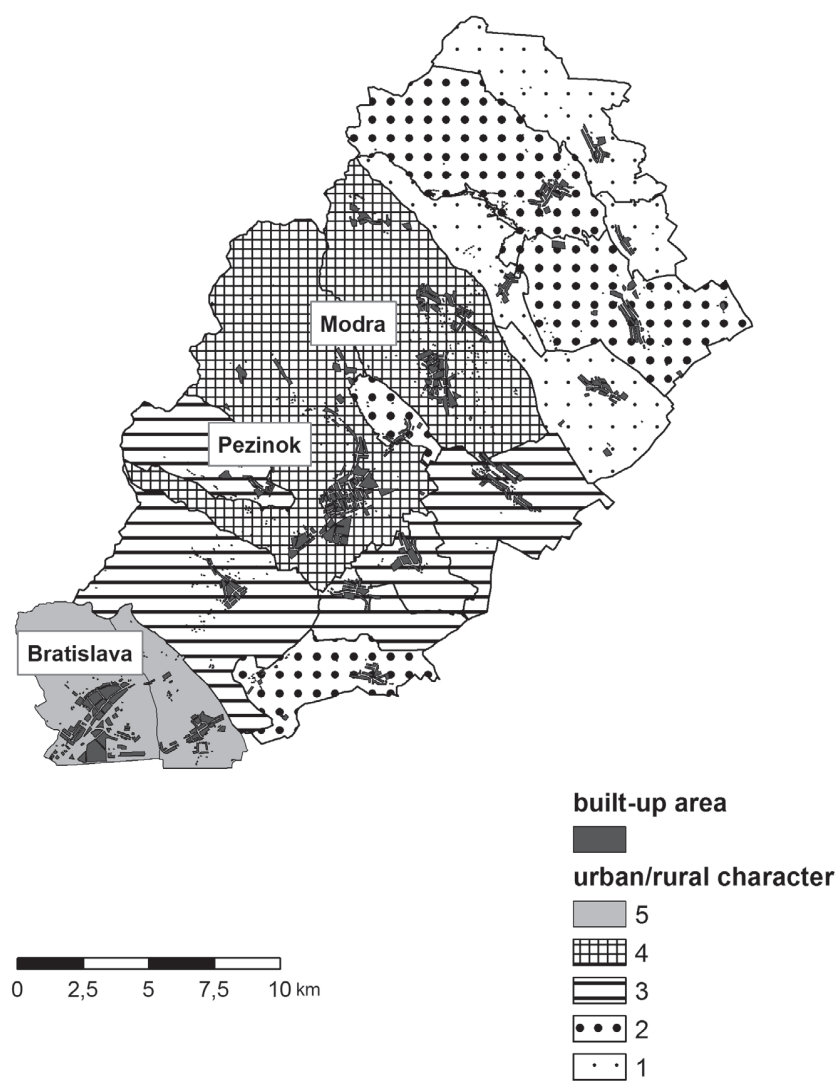

Fig. 1 Urban/rural character of the Bratislava FUR

(5 - urban, 4 -mostly urban, 3- transitive, 2 - mostly rural and 1 -rural)

- Other two biggest municipalities in the Bratislava FUR (towns Pezinok and Modra) boast mostly urban character,

- Character of municipalities on the NE edge of the region, remote from Bratislava, is either mostly rural (Vinosady, Píla, Častá, Budmerice) or rural (Vištuk, Dubová, Dol’any). Štefanová with the three principal characteristics evaluated as rural is the most rural municipality in the Bratislava FUR region.

- Establishment of the urban/rural character of other municipalities is less unambiguous:

- Demographic domain is the most important factor of urban character of the FUR (the highest degree of urbanity measured by criteria of this domain corresponds to as many as five settlements). On the contrary, the domain of life quality rather determines the rural character of the FUR (measured by the criteria of this domain, twelve settlements are rural or prevailingly rural),

- Character of the municipalities located closer to Bratislava is transitive (Chorvátsky Grob being an exception) which is stipulated by the demographic characteristics (migration out of Bratislava, rise of the housing stock). Svätý Jur (the smallest town in the region) and Limbach are typical examples, 
- The three principal domains are well balanced on the transitive level in other municipalities with transitive character (Viničné, Šenkvice, Slovenský Grob),

- Chorvátsky Grob has a very pronounced rural environmental and landscape quality and in spite of the mostly urban demographical character it is considered a mostly rural municipality.

\section{CONCLUSIONS}

The paper presents a possible alternative methodology for the determination of urban or rural character of an area. Urban or rural character of a territory is determined by the coaction of several factors of different nature, social, economic and natural. Differently from many other methodologies based on the assessment of relatively one-sided criteria (prevailingly demographic) the methodology used here tries to capture a wider spectre of factors determining the urban/rural character of a territory. The selected segment of the FUR Bratislava in the frame of the Slovak Republic represents a territory with one of the most important change gradients in urban or rural character. At the same time, there are comparatively extensive areas of a traditional cultural landscape, namely vineyards, which add a finishing touch to the singularity of the territory. The resulting disposition of urban/rural areas including some deviations basically confirms the trend of the increasing rural character of the territory with the increasing distance from Bratislava.

\section{ACKNOWLEDGEMENT}

This article is part of No. 2CE164P3 Valorisation and Sustainable Development of Cultural Landscapes Using Innovative Participation and Visualisation Techniques (acronym Vital Landscapes) Project under the CENTRAL EUROPE, Cooperating for Success Programme co-financed by the European Fund of Regional Development.

\section{REFERENCES:}

Antrop M., 2004, Landscape change and the urbanization process in Europe, Landscape and Urban Planning, 67: 9-26.

Antrop M., 2006, Sustainable landscapes: contradiction, fiction or utopia?, Landscape and Urban Planning, 75: 187-197.

Bezák A., 1990, Funkčné mestské regióny v sídelnom systéme Slovenska [Functional urban regions in the settlement system of Slovakia], Geografický časopis, 42: 57-73.

Bezák A., 2000, Funkčné mestské regióny na Slovensku [Functional urban regions in Slovakia], Geographia Slovaca, 15, Geografický ústav SAV.

Cebecauerová M., 2007, Analýza a hodnotenie zmien štruktúry krajiny [Analysis and evaluation of the landscape structure changes], Geographia Slovaca, 24, Geografický ústav SAV.

Claval P., 2005, Reading the rural landscapes, Landscape and Urban Planning, 70: 9-19.

Hahs A K., McDonnell M.J., 2006, Selecting independent measures to quantify Melbourne's urban-rural gradient, Landscape and Urban Planning, 78: 435-448.

Halfacree K.H., 2009, Urban-Rural Continuum, in Kitchin R., Thrift N. (eds.), International Encyclopedia of Human Geography, Vol. 12., Elsevier, Amsterdam - Oxford, 119-124.

Hanušin J., Huba M., Ira V., Klinec I., Podoba J., Szőllős J., 2000, Výkladový slovník termínov z trvalej udržatel’nosti (Sustainability Dictionary), Bratislava, STUŽ/SR. 
Huba M., Ira V., Chrenka B., 2010, Environmentálna situácia mestských a vidieckych obcí SR podla vybraných indikátorov [The environmental situation of urban and rural communes in the Slovak Republic according to selected indicators]. in Ira V., Podolák P. (eds.), Sídelná štruktúra Slovenska (diferenciácie v čase a priestore), Geographia Slovaca 27, Geografický ústav SAV, 57-79.

Huba M. Ira V., Chrenka B., 2011, Odlišnosti medzi rurálnym a urbánnym prostredím na Slovensku vo svetle vybraných environmentálnych ukazovatelov [Differences between the Rural and Urban Environments in Slovakia in the Light of Selected Environmental Indicators]. Životné prostredie, $45,115-118$.

Huba, M., Ira, V., Mačáková, S., Švihlová, D., Záborská, Z. (2000), Indikátory trvalo udržatel’ného rozvoja miest, [Indicators of sustainable development of cities and towns] Košice, ETP Slovensko a STUŽ/SR.

Ira V., Andráško I., 2010, Infraštruktúra a vybavenost' obcí: percepcia a hodnotenie vo vybraných regiónoch Slovenska [Infrastructure and amenities in communes: perception and assessment in selected regions of Slovakia], in Ira V., Podolák P. (eds.), Sídelná štruktúra Slovenska (diferenciácie v čase a priestore), Geographia Slovaca 27, Geografický ústav SAV, 19-40.

Jarvis H., 2005, Moving to London Time: Household co-ordination and the infrastructure of everyday life, Time \& Society, 14: 133-154.

MacGregor-Fors I., 2011, Misconceptions or misunderstandings? On the standardization of basic terms and definitions in urban ecology, Landscape and Urban Planning, 30: 347-349.

Massam B.H., 2002, Quality of life: public planning and private living, Progress in Planning, 58: 141-227.

Moravanská K., 2010, Suburbanizácia na Slovensku a jej dopady na spoločenstvá obcí, [Suburbanization in Slovakia and its impacts on rural communes], Geographia Slovaca 27, Geografický ústav SAV, 81-100.

Palang H., 2009, Evolution of the post-Soviet rural world and landscape. Proceedings from the Eight Council of Europe Workshops for the implementation of ELC, Malmö, 137-142.

Podolák P., 2007, Geografické aspekty suburbanizácie a priestorový pohyb obyvatel'stva. [Geographical aspects of suburbanization and spatial movement of population], Životné prostredie, 41: 298-302,

Podolák P., Huba M., Hanušin J., 2011, O stave a perspektívach Podmalokarpatskej kultúrnej krajiny [On state and perspectives of podmalokarpatska cultural landscape], Prognostické práce, 3: $5-25$.

Pohyb obyvatel'stva Slovenskej republiky podl'a obci v rokoch 1971-2009. [Balance of movement of the population in the Slovak republic by Communes 1971-2009 Bratislava, Štatistický úrad SR.

Primdahl J., Swaffield S., 2009, Landscape trasformation and policy challenges. Proceedings from the Eight Council of Europe Workshops for the implementation of ELC, Malmö, 143-150.

Slavík V., Kurta T., 2007, Rezidenčná suburbanizácia v zázemí Bratislavy - nový trend v migrácii obyvatelstva [Residential suburbanization in hinterland of Bratislava - new tend in migration of population], Forum Statisticum Slovacum, 3: 201-207.

Sčítanie l’udu, domov a bytov 1991, 1992, Bratislava, Štatistický úrad SR.

Sčitanie l’udu, domov a bytov 2001, 2001, Bratislava, Štatistický úrad SR.

Štatistický lexikón obcí ČSSR 1974, 1974, Praha, Federální statistický úřad. 
Šveda M., 2009, Priestorová štruktúra rezidenčnej suburbanizácie v priestorovej zóne Bratislavy [Spatial structure of residential suburbanization in the suburban zone of Bratislava], Acta Facultatis Rerum Naturalium Universitatis Comenianae, Geographica, 53: 169-182.

Toit du M., Cilliers S.S., 2011, Aspects influencing the selection of representative urbanization measures to quantify urban-rural gradients. Landscape Ecology, 26: 169-181. 